\title{
Pregnancy Bony Imprint on Japanese Female Pelves and Its Relation to Pregnancy Experience
}

\author{
Yuriko IGARASHI \\ Laboratory of Physical Anthropology, Faculty of Science, \\ Kyoto University
}

\begin{abstract}
Pelvic bones from 20 modern-Japanese female cadavers were examined in order to ascertain the relationship between the bony scar in the pre-auricular area of the ilium and pregnancies and/or parturitions. The age of cadavers ranged from 49 to 99 years. Sixteen women were reported to have born some children, and four were reported to have never given birth. In several cases, additional information on the number and spacing of deliveries and miscarriages was obtained. The scars were classified into three categories: PP (marked), P (moderate) and N (absent). It can be hypothesized that the scars result from the experience of pregnancy rather than parturition, that their development is possibly related to the number of pregnancies, and that they do not disappear even 18-65 years after the last childbirth.
\end{abstract}

Key Words Bony scar, Pre-auricular area, Pregnancy imprint, Japanese

\section{Introduction}

Many researchers have carried out studies on the bony scars which are characteristic of female pelves, in relation to pregnancy and/or parturition (HougTON, 1974, 1975). The scars appear in the shape of pits or grooves on the dorsal surface of the pubic symphysis and/or in the preauricular area of the ilium. PUTSCHAR (1931) described, for the first time, histological changes brought about by pregnancy and childbirth at the pubic symphysis and the sacroiliac joint of the female pelvis. He studied pelves of female cadavers who had died during pregnancy or just after childbirth, and reported that in the woman after delivery, cartilages at the pubic symphysis and/or sacroiliac joint were torn, cysts containing cartilaginous fragments had formed, and osteoclasts increased in number. He also recognized ligamentous hyperplasia at the pubic symphysis of nulliparous women in the fourth week to the sixth month of pregnancy. Furthermore, PUTSCHAR (1976) has noted a bony groove on the dorsal surface of the pubic symphysis of the female pelvis, and suggested that it may be caused by the intrusion of these hypertrophic ligaments.

Many scholars have attempted to explore the relationship between scar formation, pregnancies, and parturitions, using modern female pelves. HOUGTON (1975), DUNLAP (1979), and ISCAN and DUNLAP (1984) have ascribed the scars to the course of pregnancy, whereas KELLEY (1979), SUCHEY et al., (1979), and BERGFELDER and HERRMANN (1980) have concluded that the

Article No. 9204 Received May 8, 1992 
scars are caused by parturition. However, HOLT (1978), SPRING et al., (1984), and SPRING et al., (1989) have been skeptical of any relationship.

Importantly, HOUGTON (1974, 1975), DUNLAP (1979), and KELLEY (1979) have concluded that the pre-auricular area is more sensitive to scaring than the pubic symphysis. According to HougTON $(1974,1975)$, the reason is as follows: the sacroiliac joint is in the direct line of body weight transfer, and its ligaments are under the great stress of increased weight for many months of pregnancy.

On the other hand, NEMESKERI (1972) and ULLRICH (1975) examined archaeologically excavated pelves, classified the scars into several stages according to the development, and allocated a certain number of childbirths to each stage. Studying female pelvic bones which were unearthed from archaeological sites, ULLRICH (1975), PHILliPPS (1980) and POLLOCK (1987) estimated the number of childbirths per individual woman on the basis of ULLRICH's (1975) standard, and discussed fertility in an ancient society.

However, we do not have any positive evidence that there is a correlation between the development of the scars and the number of pregnancies and/or parturitions. The present

Table 1. Intensity of the scar in the pre-auricular area on every subject, along with the information on deliveries, miscarriages, the ages at death and at the last birth

\begin{tabular}{|c|c|c|c|c|c|c|}
\hline Individual & $\begin{array}{l}\text { Intensity of } \\
\text { the scar }\end{array}$ & $\begin{array}{l}\text { Number of } \\
\text { deliveries }\end{array}$ & $\begin{array}{l}\text { Number of } \\
\text { deliveries and } \\
\text { miscarriages }\end{array}$ & $\begin{array}{l}\text { Age at } \\
\text { death } \\
\text { (years) } \\
\quad \text { A }\end{array}$ & $\begin{array}{l}\text { Age at the } \\
\text { last birth } \\
\text { (years) } \\
\text { B }\end{array}$ & $\begin{array}{c}\text { A-B } \\
\text { (years) }\end{array}$ \\
\hline 1 & $P$ & 3 & 3 & 89 & 24 & 65 \\
\hline 2 & $\mathrm{P}$ & 6 & 6 & 82 & 32 & 50 \\
\hline 3 & PP & 2 & 6 & 89 & 24 & 65 \\
\hline 4 & PP & 6 & 7 & 81 & 42 & 39 \\
\hline 5 & PP & 9 & 9 & 87 & 45 & 42 \\
\hline 6 & $\mathbf{P}$ & 5 & & 55 & 37 & 18 \\
\hline 7 & $\mathbf{P}$ & 4 & & 61 & & \\
\hline 8 & $\mathbf{P}$ & 4 & & 82 & & \\
\hline 9 & $\mathbf{P}$ & $1+$ & & 99 & & \\
\hline 10 & $\mathbf{P}$ & $1+$ & & 88 & & \\
\hline 11 & $\mathbf{P}$ & $2+$ & & 91 & & \\
\hline 12 & $P$ & $2+$ & & 73 & & \\
\hline 13 & $P$ & $2+$ & & 78 & & \\
\hline 14 & $\mathrm{P}$ & $1+$ & & 83 & & \\
\hline 15 & $P$ & $1+$ & & 70 & & \\
\hline 16 & PP & $2+$ & & 68 & & \\
\hline 17 & $\mathrm{~N}$ & 0 & & 49 & & \\
\hline 18 & $\mathbf{P}$ & 0 & & 65 & & \\
\hline 19 & $P$ & 0 & & 91 & & \\
\hline 20 & $P$ & 0 & & 88 & & \\
\hline
\end{tabular}

The number of deliveries with " +" denotes the minimum number of deliveries. 


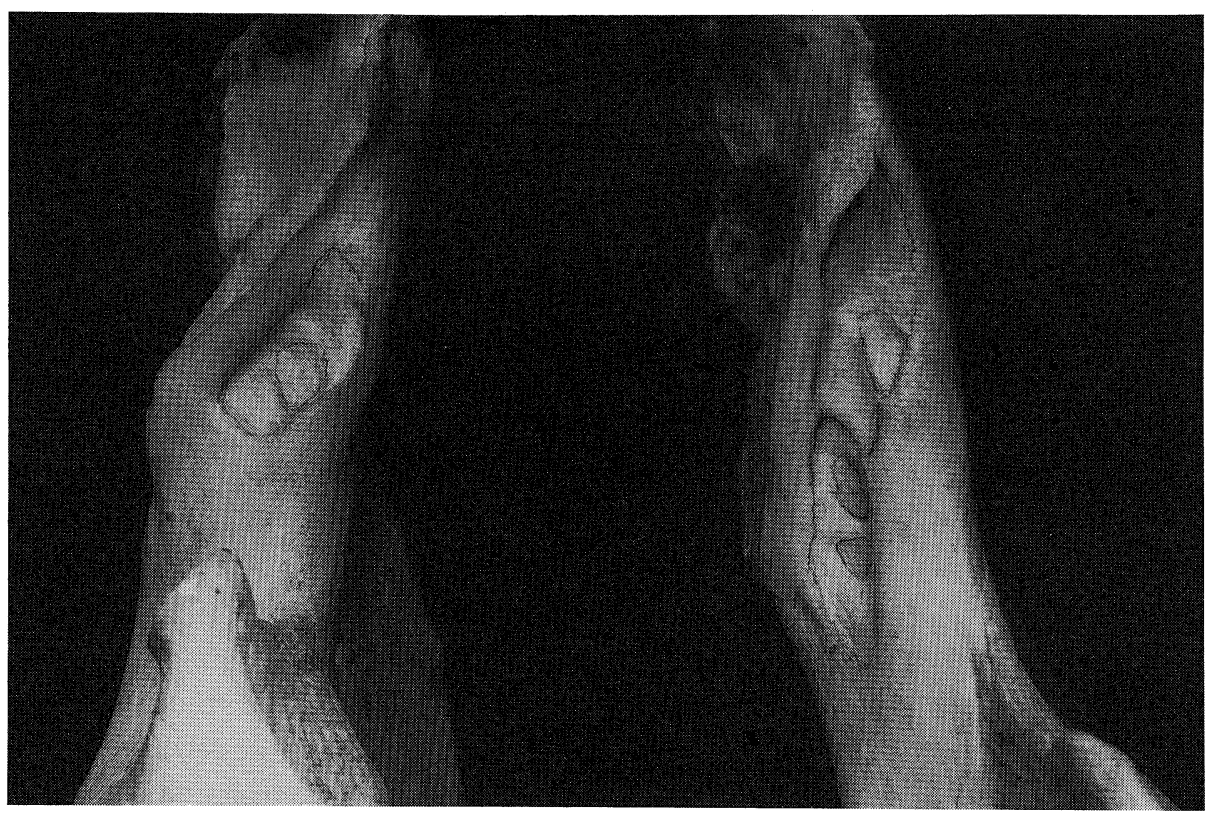

Fig. 1. The scar of PP: the groove contour is complete and not parallel to the marginal line of the auricular surface, and accompanied with a pit structure inside.

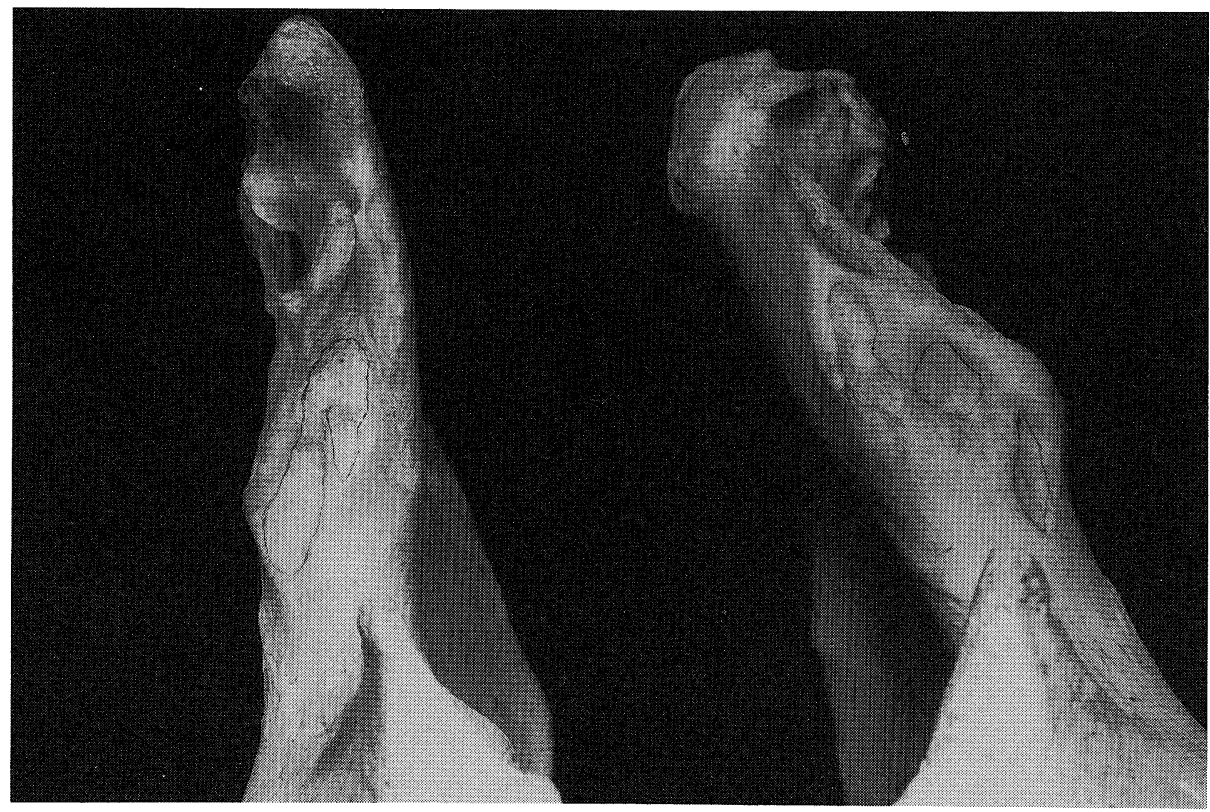

Fig. 2. The scar of $P$ : the pit or groove contour is complete and not parallel to the marginal line of the auricular surface, but without a pit structure inside. 
study anatomically examines the form of the scar, especially in the pre-auricular area of the ilium, of the cadaver material of modern-Japanese women, and classified the scars by a new criteria in order to ascertain the relationship between the scar and pregnancies and/or parturitions.

\section{Materials and Methods}

Pelvic bones from 20 modern-Japanese female cadavers were examined in the dissection room at several institutions: seven cadavers at Osaka City University Medical School, six at Sapporo Medical College, four at Kansai Medical University, and three at Showa University. Age at death and the childbearing experience were derived from records submitted by families to the institutions. Ages ranged from 49 to 99 years. Of the 20 women, $16(80 \%)$ had born some children. In several cases, additional data on the number and spacing of deliveries and miscarriages were obtained through a questionnaire from family members (Table 1).

The scars were classified into three categories: $\mathrm{PP}, \mathrm{P}$ and $\mathrm{N}$. The categories were defined through a preliminary investigation of modernJapanese skeletal series.

The PP denotes that the pit or groove contour is complete and not parallel to the marginal line of the auricular surface, and accompanied with a pit structure inside (Fig. 1). In the $P$ category scar, the pit or groove contour is the same as in the PP category, but without a pit structure inside (Fig. 2). The pitting or grooving is more well-developed in the PP category than in the $P$. The $N$ includes the cases in which there are no pits or grooves (Fig. 3), the pit or groove contour is not complete or the contour is parallel to the marginal line of the auricular surface (Figs. 4 and 5). In the preliminary investigation, the PP and the $\mathrm{P}$ categories were observed only among adult females, whereas the $\mathrm{N}$ category was observed among both males and females.

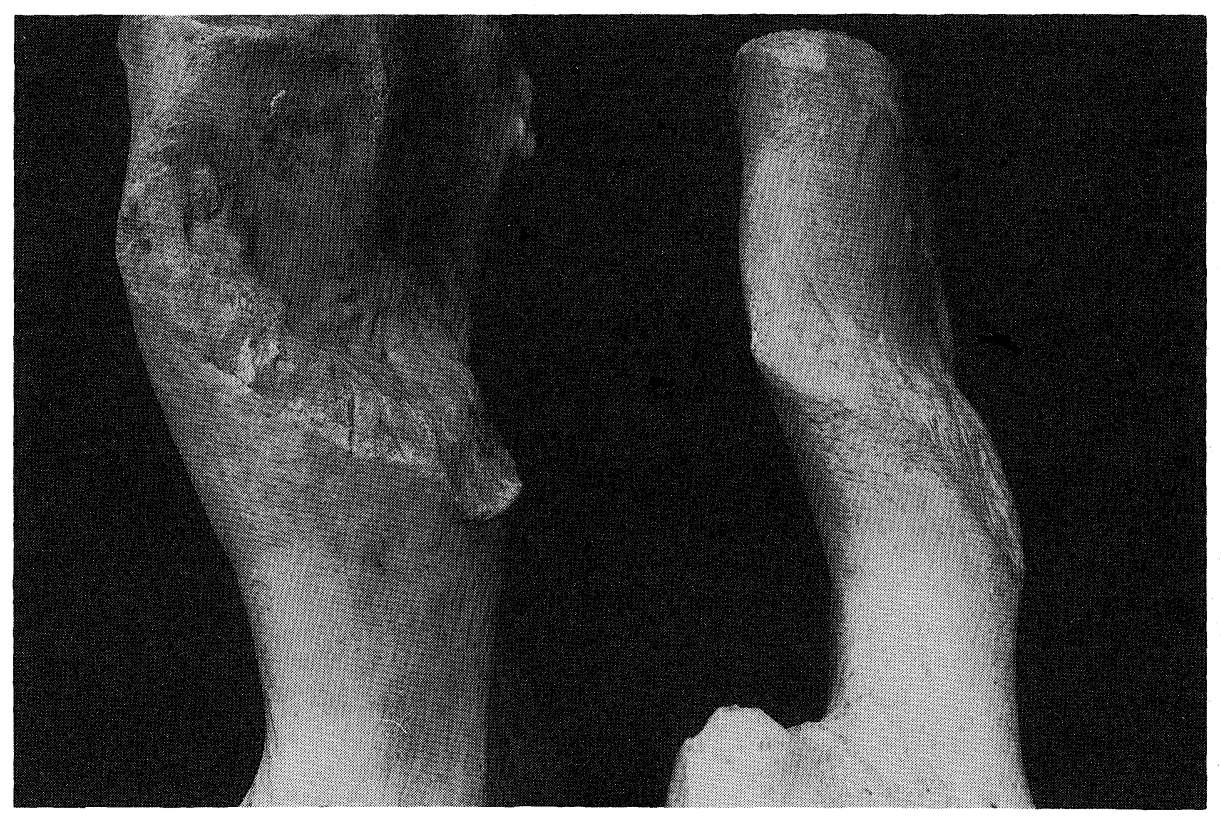

Fig. 3. The scar of $\mathrm{N}$ : no pit nor groove. 


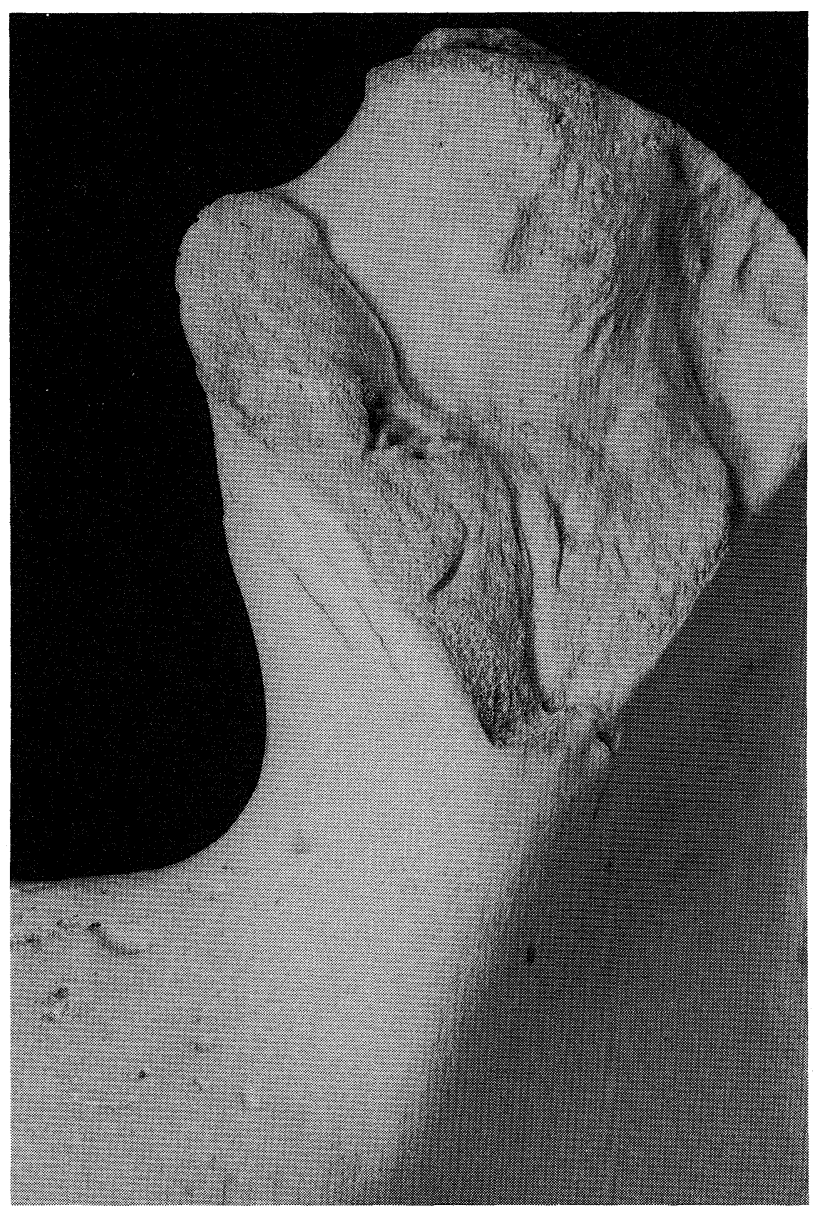

Fig. 4. The scar of $\mathrm{N}$ : the groove contour is not complete and parallel to the marginal line of the auricular surface.

Therefore, it is supposed that the PP and P category scars are related to pregnancy and/or parturition, and that $\mathrm{N}$ category scars may be caused by strong ligaments, as suggested by HOUGHTON (1974). Moreover, the development of the PP category scar is more clearly marked than that of the P. Accordingly, the PP and the P represent the marked scar and the moderate scar, respectively, and the $\mathrm{N}$ represents the condition where the scar is absent.
In the examination of the cadavers, the preauricular area of the ilium was observed macroanatomically after removing the soft tissues. The assessment of the scar was carried out independently on the left and right sides. In the case where the scars were judged differently on both sides, the stronger scars were used for analysis. There were four such cases out of 20: in two individuals, both PP and P category scars occurred on their pelves, and in the other two cases, both 


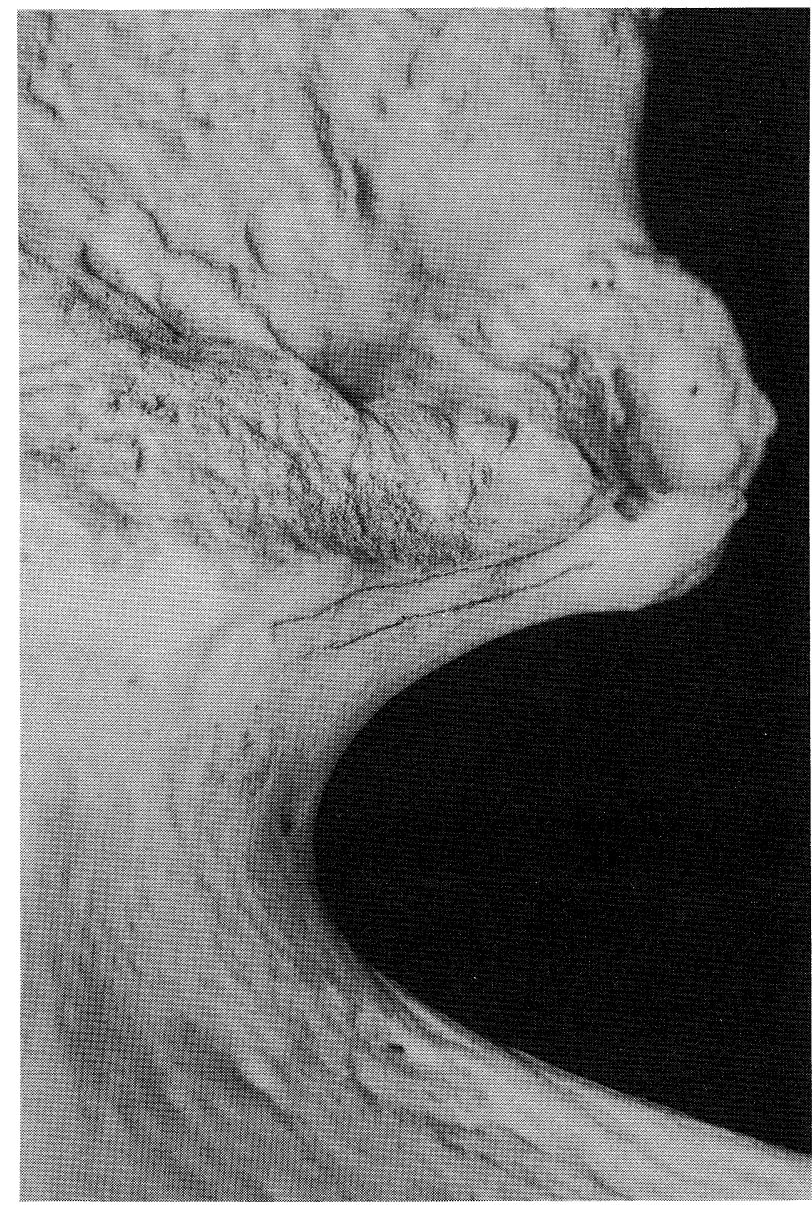

Fig. 5. The scar of $\mathrm{N}$ : the groove contour is not complete.

$\mathrm{P}$ and $\mathbf{N}$ category scars occurred. In one individual, only one side was available to assess the scar.

\section{Results and Discussion}

Table 1 lists the extent of the scar on the subjects, along with available information on deliveries, miscarriages, and the ages at death and at the last childbirth. Table 2 presents the assortment of the subjects according to the scar category and the number of deliveries. Tables 1 and
Table 2. Assortment of the subjects according to the category of the scar in the pre-auricular area and the number of deliveries

\begin{tabular}{lrrrr}
\hline & PP & P & N & Total \\
\hline Multipara & 4 & 12 & 0 & 16 \\
Nullipara & 0 & 3 & 1 & 4 \\
\hline Total & 4 & 15 & 1 & 20 \\
\hline
\end{tabular}




\section{O woman with PP $\bigcirc$ woman with $P$}

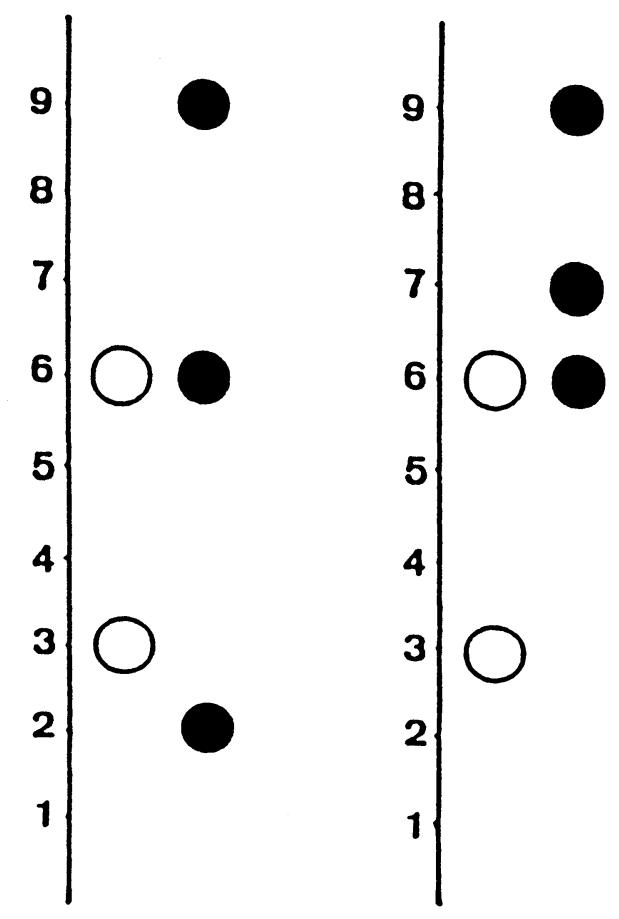

Fig. 6. Distribution of the women by the number of deliveries (left) and by the combined number of deliveries and miscarriages (right).

2 indicate that every woman with PP had experienced childbirth, and that only one was judged to be $\mathrm{N}$, and she had not born any children. The data suggest a possible relationship between childbirths and the scars.

Fig. 6 illustrates the distribution of the numbers of deliveries and miscarriages for the five women (Nos. 1-5) with available data. For the number of deliveries, the PP women and the $\mathbf{P}$ women overlap in distribution. On the other hand, for the combined number of deliveries and miscarriages, it is clear that the PP women tend to be greater in the combined number of deliveries and miscarriages than the $\mathrm{P}$ women.
The difference in distribution comes from the number of miscarriages of two of the PP women (Nos. 3 and 4). It can be hypothesized that the development of the scars is related to the combined number of deliveries and miscarriages, which is the number of pregnancies, and that the PP category scars indicate more experience of pregnancies than the $\mathrm{P}$ category scars.

Of four females (No. 17-20) who were reported to be nulliparous, three had the $\mathrm{P}$ scar indicating pregnancy experiences. It is possible that the three nulliparous women had experienced some miscarriages, although not enough data was available for these women. ISCAN and DUNLAP (1984) reported that pregnancy changes at pelvic joints were observed in two nulliparous women who had been pregnant.

The scars do not disappear for a long period after the last childbirth. The data was available on the age at the last childbirth for six individuals (Nos. 1-6). They were calculated to have died 18-65 years after the last childbirth. Of them, three had PP category scars and the other three, $P$ category scars.

In conclusion, it can be hypothesized that the pit or groove-like scar in the pre-auricular area of the ilium is ascribed to the experience of pregnancies rather than parturitions, and that its development is possibly related to the number of pregnancies, and that it does not disappear even 18-65 years after the last childbirth. Thus, the present study supports the presence of a causative relation between the scars and pregnancy, as suggested by PUTSCHAR (1976), HOUGHTON (1975), DUNLAP (1979), and ISCAN and DUNLAP (1984). Therefore, as HOUGHTON (1975) suggested, this scar should be named the "pregnancy bony imprint".

\section{Acknowledgement}

I am deeply indebted to Dr. K. KATAYAMA of Laboratory of Physical Anthropology, Kyoto 
University for valuable advice and for reading the manuscript. I am grateful to Dr. A. TAGAYA of Osaka City University Medical School, Prof. Y. DODO of Sapporo Medical College, Dr. S. HAYAMA of Kansai Medical University, Dr. H. KUMAKURA of Osaka University, for the arrangements to examine the dissection cadavers and for kind help to gather valuable information about the cadavers. I express my gratitude to the directors of the institutions for the permission to examine the cadavers. I would like to thank to Dr. David SPRAGUE for reading the manuscript. I wish to acknowledge helpful discussions with the members of the Laboratory of Physical Anthropology, Faculty of Science, Kyoto University.

$$
\text { 抄録 }
$$

日本人女性骨盤の妊娠痕について

\section{五十嵐 由里子}

現代日本人女性の遺体20体について, 腸骨耳状面の 前下部に認められ，妊娠や出産に関係すると考えられ ている洼みや溝を観察し，その強さと，妊娠や出産の 経験との関係を調べた。遺体の死亡年齢は49歳から 99 歳にわたり，このうち出産の経験がある者は 16 体で あった，出産や流産についての情報は，家族へのアン ケートによって得た。これらの窪みや強さは，事前に 近代日本人の骨格標本の骨盤を調查して作った三段階 の基準（強い，弱い，無し）に従って判定した.

その結果, 強い窪みや溝は経産婦にのみ現れ, 窪み や溝が無いと判定された 1 例は未産婦であった (Table 1 と2).さらに, 妊娠と出産の回数がわかっ た個体について,これらの窪みや溝の出現状況を分析 した結果, これらの特徴が出産の際にではなく妊娠の 間に形成され，その強さは妊娠の回数とある程度の相 関を持つことが示唆できた（Fig. 6)。また，最終出 産後18年から65年たっても，これらの窪みや溝は消え ないことがわかった（Table 1).

\section{References}

BERGFELDER, T. and B. HERRMANN, 1980: Estimating fertility on the basis of birth-traumatic changes in the pubic bone. J. Hum. Evol., 9: 611-613.

DUNLAP, S.S., 1979: Sex, parity and the preauricular sulcus. Am. J. Phys. Anthropol., 50: 434.

HOLT, C.A., 1978: A re-examination of parturition scars on the human female pelvis. Am. J. Phys. Anthropol., 49: 91-94.

HOUGHTON, P., 1974: The relationship of the preauricular groove of the ilium to pregnancy. Am. J. Phys. Anthropol., 41: 381-390.

HOUGHTON, P., 1975: The bony imprint of pregnancy. Bulletin of the New York Academy of Medicine, 51: 655-661.

ISCAN, M.Y. and S.S. DUNLAP, 1984: Anterior and posterior pelvic joint relationships in a cadaver population of known obstetrical history. Am. J. Phys. Anthropol., 63: 174.

KELlEY, M.A., 1979: Parturition and pelvic changes. Am. J. Phys. Anthropol., 51: 541-546.

NEMESKÉRI, J., 1972: Die archäologischen und anthropologischen Voraussetzungen paläodemographischer Forschungen. Praehistorische Zeitschrift, 47: 5-46.

PHILlIPPS, M.A.L., 1980: An estimation of fertility in prehistoric New Zealanders. New Zealand J. of Archaeology, 2: 149-157.

POLLOCK, H.J., 1987: Biological coherence at Khok Phanom Di. B.A. (HONS) Dissertation, University of Otago, New Zealand.

PUTSCHAR, W.G.J., 1931: Entwicklung, Wachstum und Pathologie der Beckenverbindungen des Menschen mit besonderer Berücksichtigung vor Schwangerschaft, Geburt und ihren Folgen. Gustav Fischer, Jena., pp.70-116, 154-161.

PUTSCHAR, W.G.J., 1976: The structure of the human symphysis pubis with special consideration of parturition and its sequelae. Am. J. Phys. Anthropol., 45: 589-594.

SPRING, D.B., G.N. BENDER and C.O. LOVEJOY, 1984: The radiographic preauricular groove: its nonrelationship to pregnancy. Am. J. Phys. Anthropol., 63: 220 .

SPRING, D.B., C.O. LOVEJOY, G.N. BENDER and M. DUERR, 1989: The radiographic preauricular groove: its non-relationship to past parity. Am. J. Phys. Anthropol., 79: 247-252.

SUCHEY, J.M., D.V. WISELEY, R.F. GREEN and T.T. NOGUCHI, 1979: Analysis of dorsal pitting in the os pubis in an extensive sample of modern American females. Am. J. Phys. Anthropol., 51: 517-540.

ULLRICH, H., 1975: Estimation of fertility by means of pregnancy and childbirth alterations at the pubis, the ilium, and the sacrum. OSSA., 2: 23-39. 
五十嵐 由里子京都大学理学部自然人類学研究室

₹606 京都市左京区北白川追分町

Yuriko IGARASHI Laboratory of Physical Anthropology,

Faculty of Science, Kyoto University

Kitashirakawa Oiwake-cho,

Sakyo-ku, Kyoto 606, Japan 